\title{
GEDRAGSVERBREDING: 'N NUWE KONSEP IN TOESIGHOUDING
}

\author{
A.D. DE BOD* \\ J.H. GARNER \\ AFDELING MANNEKRAG \\ SUID-AFRIKAANSE VERVOERDIENSTE
}

\begin{abstract}
Behaviour expansion is a training technology developed specifically to enable the supervisor to perform effectively in various situations. The technology is conceptually described by coupling it to existing learning theories and training techniques. The operationalization of the technology by developing and experimentally evaluating a behaviour expansion course $(N=60$ supervisors) is also discussed. The results show that supervisors, through behaviour expansion training are able to handle interpersonal situations more effectively, develop a broad repertoire of behaviour and exhibit a higher degree of task and person orientation.
\end{abstract}

Uit 'n oorsig van navorsing wat sedert die vyftigerjare binne die breë veld van motivering onderneem is (Maslow, 1954; Herzberg, Mausner \& Snyderman, 1959; White, 1959; Vroom, 1964; Hall \& Nougaim, 1968; Alderfer, 1969; Huizinga, 1970; Blackler \& Williams, 1971; Wofford, 1971; Backer, 1973; Lawler, 1973; Wahba \& Bridwell, 1976) is dit opvallend dat dieselfde faktore hoofsaaklik vir die motivering van die individu in die organisasie verantwoordelik is. Hierdie faktore is salaris, medewerkers, groei- en vooruitganggeleenthede, posinhoud en kwaliteit van toesighouding.

Die toesighouer het weinig, indien enige, beheer oor die meeste van hierdie faktore. Hy het min seggenskap oor die grootte van sy ondergeskiktes se salaristjek, hy kan nie sy werkers self kies nie, trouens hy moet vat wat hy van die personeeldepartement kry en hy kan nie bevorderingskanale vir sy ondergeskiktes skep nie aangesien dit in die organisasiestruktuur en beleid van die organisasie vasgelê is. Hoewel posbeskrywings in 'n groot mate die aard en omvang van posinhoud vaspen, kan die toesighouer sy ondergeskiktes se werk deur kleinere aanpassings verryk. Hy kan ook in 'n beperkte mate sy ondergeskiktes met meer en groter

\footnotetext{
${ }^{*}$ Versoeke vir afdrukke moet aan die eerste skrywer gerig word.
} 
verantwoordelikhede beklee en sodoende bydra tot hul persoonlike groei. Sy beheer oor hierdie faktore bly egter maar gering.

Die enigste faktor waaroor die toesighouer werklik volkome beheer het is die kwaliteit van sy toesighouding. Hieruit volg logies dat die motiveringsklimaat wat binne die toesighouer se bepaalde groep geskep word, primêr afhanklik is van die kwaliteit van sy toesighouding. Dit is derhalwe vir die organisasie van die uiterste belang dat sy toesighouers 'n hoë kwaliteit van toesighouding moet handhaaf. Een manier waarop die organisasie 'n hoë kwaliteit van toesighouding kan verseker, is om sy toesighouers voortdurend op te lei.

Die behoefte aan toesighoueropleiding is geensins nuut nie, die vraag is net waarin moet die organisasie sy toesighouers oplei. Die antwoord hierop is grootliks geleë in die aard van die toesighouer se werk.

\section{DIE AARD VAN TOESIGHOUDING}

Tradisioneel word die toesighouer se werk beskryf in terme van vier algemene funksies, naamlik beplanning, organisering, leiding en kontrole (PLOC, "planning", "leading", "organising", "control"). Hierdie teoretiese beskrywing van die toesighouer se werk is ontleen aan Fayol (1916) se klassieke bestuursmodel wat die bestuurstaak in terme van soortgelyke "handelinge" beskryf. Sedertdien is hierdie teoretiese beskrywing van bestuurswerk ywerig voortgesit, soveel so dat daar vandag bykans nie 'n handboek oor bestuur is wat nie op een of ander wyse, al is dit dan onder name, na Fayol (1916) se bestuursfunksies verwys nie (vergelyk Gulick \& Urwick, 1937; Davis, 1940; Koontz \& O'Donnel, 1955; Newman, Summer \& Warren, 1967; Albers, 1969; Haimann \& Scott, 1974; Conner, 1978).

Die grootste probleem met die teoretiese ontleding van bestuurswerk is dat dit die bestuurder en toesighouer se taak te veel veralgemeen. Dit misken inderdaad die diversiteit van bestuur- en toesighouerposte (Stewart, 1963). Derhalwe is daar 'n behoefte aan beskrywings van dit wat die bestuurder en toesighouer werklik doen.

Hierdie behoefte is reeds deur bestuursdenkers raakgesien en sommige het hul tot direkte waarneming gewend in 'n poging om te beskryf wat die bestuurder en toesighouer werklik doen. Guest (1956) het waarskynlik die eerste studie gedoen oor hoe toesighouers daagliks langer as 'n normale werksdag werk, elke dag 'n wye verskeidenheid insidente hanteer en bykans $60 \%$ van sy tyd aan persoon-tot-persoon kommunikasie bestee. 
Soortgelyke navorsing is in latere jare op ander bestuursvlakke deur Burns (1957), Copeman, Luijk en Hanika (1963), Stewart (1963), Horne en Lupton (1965) en Mintzberg (1973) onderneem.

Die resultate van hulle werk kom, in die geheel gesien, daarop neer dat bestuur- en toesighouerwerk te gediversifiseerd is om enigsins volledig beskryf te word deur ' $n$ paar veralgemeende funksies. Hiermee word gesuggureer dat die tradisionele siening van die bestuurder en toesighouer se taak in terme van beplanning, organisering, besluitneming, leiding en kontrole, verouderd en uitgedien geraak het. Horne en Lupton (1965, p. 32) som dit die beste op: "Middle management does not seem, on this showing, to require the exercise of remarkable powers to analyse, weigh alternatives and decide. Rather, it calls for the ability to shape and utilise the person-to-person channels of communication, to influence, to persuade, to facilitate".

Dit is egter nie net die taak van die toesighouer wat oor die jare heen verander het nie, maar terselfdertyd was daar ook 'n waarneembare verandering in die kenmerke van die arbeidsmag. Mense wat vandag tot die arbeidsmark toetree, het in 'n algeheel ander milieu groot geword as mense wat twintig, dertig jaar gelede die mark betree het. Opvoedingsmetodes het meer wetenskaplik gefundeerd geraak, vryheid (veral van spraak) het 'n credo geword, die beskerming van individuele regte het 'n voldonge feit geword en dit wil voorkom of outokrasie op verskeie terreine (maar veral in bestuur) vir demokrasie plek maak.

Hierdie veranderinge het 'n ooglopend "nuwe generasie werker" voortgebring. 'n Werker wat relatief jonk is, bewus is van sy ekonomiese regte en vryhede (veral vandag onder die nuwe arbeidswetgewing) en hoë aspirasies en verwagtings het. Dit wil voorkom of die "nuwe generasie werker" meer onafhanklik is, homself wil uitleef, nie hou van organisatoriese beperkings nie, nie rigiditeit kan verdra nie en 'n hekel aan outoriteit het. Uit hierdie penskets van die "anatomie" van die "nuwe generasie werker" is dit duidelik dat die toesighouer sy ondergeskiktes verskillend sal moet hanteer as dit waaraan hy tot dusver gewoond was. Die harde benadering ("doen dit of ... ") is hoegenaamd nie meer effektief nie en derhalwe het dit nodig geword dat toesighouers nuwe vaardighede geleer word om die "nuwe generasie werker" te hanteer.

Om 'n vaardigheid aan te leer is dit nodig om gedrag te verander (Hinrichs, 1976) en derhalwe is dit van kritieke belang dat die opleidingstegnologie wat gebruik word om die toesighouer die vaardighede te leer om die "nuwe generasie werker" te hanteer, in staat moet 
wees om 'n verandering van gedrag te bewerkstellig. Die opleidingstegnologie wat spesifiek vir hierdie doel ontwikkel is, staan bekend as gedragsmodelering ("behaviour modeling").

\section{GEDRAGSMODELERING}

Sorcher (1971) het in 1970 by die General Electric Maatskappy met die beginsels van gedragsmodifikasie (Bandura, 1969), wat primêr 'n terapeutiese tegniek is, begin eksperimenteer in 'n poging om toesighouers met vaardighede te beklee wat hulle in staat sou stel om hulle ondergeskiktes doeltreffend te hanteer. Die inisiële resultate was besonder positief (Sorcher, 1971) en daaropvolgende toepassings het gelei tot die formulering van gedragsmodelering as 'n nuwe opleidingstegnologie. Die rasionaal onderliggend aan gedragsmodelering is dat gedrag direk verander word deur middel van nabootsing van modelgedrag, oefening van die modelgedrag en versterking van gemodeleerde gedrag deur terugvoering (Goldstein \& Sorcher, 1974; Johnson \& Sorcher, 1976).

Die teorie van nagebootsde leer ("imitative learning") strek so ver terug as 1896 toe studies in hierdie verband uitgevoer is. Nagebootsde leer of meer korrek, "modelering", is 'n handige manier om die leerproses te fasiliteer wanneer komplekse gedragspatrone aangeleer word (Wehrenberg \& Kuhnle, 1980). Ons is trouens elke dag by modelering betrokke. Dink maar aan 'n seuntjie wat vir die eerste keer leer om 'n elektriese speelgoedmotortjie te hanteer. Sy vader sal waarskynlik vir hom wys hoe om die motortjie aan te skakel, te versnel en te stop (model) en daarna sal hy sy seuntjie 'n geleentheid gee om dit self te doen (oefening). As die seuntjie die korrekte gedrag openbaar word hy beloon met iets soos "slim seun", "mooi", "pa se groot kind", ensovoorts (versterking en as hy fouteer (verkeerde gedrag openbaar), word hy gesê wat hy verkeerd gedoen het en hoe hy dit beter kan doen (terugvoering).

Gedragsmodelering het oor die afgelope dekade, maar veral sedert die publikasie van Goldstein en Sorcher se boek Changing Supervisory Behavior in 1974, oor 'n breë front in nywerheidsopleiding toepassing gevind. Dit het veral 'n populêre metode geword om toesighouers en bestuurders op te lei om interaksiesituasies doeltreffend te hanteer.

Gedragsmodelering word ook al vir 'n geruime tyd in Suid-Afrika in bestuurs- en toesighoueropleiding gebruik (Sorcher, 1975). Daar is trouens onlangs begin om die tegniek te gebruik om rasseverhoudings in die werksituasie te verbeter (Albrecht, 1980). 
Gedragsmodelering is nie net teoreties grondig gefundeer nie, maar beskik as opleidingstegnologie ook oor 'n stewige empiriese fundering (Dicken, 1980). Verskeie navorsingstudies (Goldstein \& Sorcher, 1974; Burnaska, 1976; Moses \& Ritchie, 1976; Byham, Adams \& Kiggins, 1976; Kraut, 1976; Latham \& Saari, 1979; Petasis \& Hancock, 1979) het aangetoon dat 'n positiewe opleidingseffek met behulp van gedragsmodelering behaal word.

Ondanks hierdie positiewe bevindings is daar in die jongste verlede ook kritiek teen die tegniek van gedragsmodelering uitgespreek. Hierdie kritiek (McGhee \& Tullar, 1978) moet veral gesien word as 'n waarskuwing dat die eksperimentele ontwerpe van die meeste studies wat die effek van gedragsmodelering ondersoek het, soveel statistiese beperkinge op die data plaas dat die resultate van sodanige studies (Burnaska, 1976; Moses \& Ritchie, 1976; Byham, Adams \& Kiggins, 1976; Smith, 1976) nie sonder meer aanvaar kan word as positiewe getuienis ten gunste van die tegniek nie.

In die populêre gesprekvoering is daar ook al vraagtekens oor die tegniek van gedragsmodelering geplaas (Locke, 1977; Robinson, 1980). Een van die belangrikste besware wat teen die tegniek ingebring kan word, is dat die onderliggende leerproses so gestruktureerd is dat dit nie enige ruimte laat vir die individu (leerling) se besondere leerbehoeftes nie. Verder word hier, soos wat dit paslik deur die naam gedragsmodelering aangedui word, uitsluitlik op die aanleer van 'n positiewe gedragsmodel gefokus.

In 'n tipiese gedragsmodeleringsessie word die leerervaring beperk tot die aanleer van 'n stel leerpunte wat in die hantering van 'n spesifieke werkverwante interpersoonlike situasie gevolg moet word. So byvoorbeeld moet die leerling in die "verwelkoming van 'n nuwe werker" (werkverwante interpersoonlike situasie) die nuweling "op sy gemak stel" (leerpunt). Die leerling oefen hierdie leerpunte in 'n poging om dit net so goed soos die model na te volg. Dit is juis in hierdie besondere beginsel van gedragsmodelering wat daar 'n bedekte gevaar lê in die sin dat die leerling eintlik leer om 'n kunsmatige nabootser van positiewe gedrag te word, eerder as om 'n natuurlike demonstreerder van positiewe gedrag te word.

Goldstein en Sorcher (1974) se teoretiese rasionaal agter hierdie beginsel van gedragsmodelering is dat die aanhoudende nabootsing van die leerpunte uiteindelik tot 'n veranderde en gevestigde gedragspatroon sal lei. Ons uitgangspunt is egter dat 'n veranderde gedragspatroon slegs gevestig kan word indien gedragsvaardighede wat onderliggend is aan die leerpunte van 'n spesifieke interpersoonlike situasie, aangeleer (maar verkieslik geïnternaliseer) word. Hierdie stelling word nie maar bloot intuïtief gemaak nie, maar berus 
op die resultate van 'n waarnemingstudie wat onderneem is om te bepaal of daar wel sekere fundamentele gedragsvaardighede onderliggend is aan die leerpunte wat in tipiese gedragsmodeleringsessies gebruik word om toesighouers in staat te stel om werkverwante interpersoonlike situasies te hanteer.

\section{DIE WAARNEMINGSTUDIE}

Gedurende 1980 was die skrywers betrokke by die ontwikkeling van drie kursusse wat daarop gemik was om die interpersoonlike vaardighede van drie verskillende teikengroepe (werkswinkeltoesighouers, $\mathrm{N}=78$; administratiewe middelvlakbestuurders, $\mathrm{N}=28$; publieke diensbestuurders, $\mathrm{N}=24$ ) te verhoog. In al drie kursusse is van gedragsmodelering as opleidingstegnologie gebruik gemaak.

Die tipiese interpersoonlike situasies wat die teikengroepe gereeld hanteer, is deur middel van posontleding (onderhoudvoeringstegniek) identifiseer. Nege verskillende situasies is geïdentifiseer, waarvan drie gemeenskaplik tot die drie teikengroepe was, terwyl twee "unieke" situasies (situasies wat eie is aan die besondere teikengroep) vir elke teikengroep deur die posontleding na vore gekom het. Vir elke situasie is 'n stel leerpunte asook videomodelle volgens Goldstein en Sorcher (1974) se voorskrifte ontwikkel.

Die kursusse is deur bedryfsielkundiges hanteer wat in die tegniek van gedragsmodelering opgelei is. Al die opleidingsessies is streng volgens die beginsels van gedragsmodelering (vergelyk Goldstein \& Sorcher, 1974; Johnson \& Sorcher, 1976; Wehrenberg \& Kuhnle, 1980) hanteer. Om egter die mikpunt van die waarnemingstudie te toets, was dit nodig om die verloop van die vaardigheidsoefeninge, wat 'n belangrike deel van enige gedragsmodeleringsessie uitmaak, waar te neem, pleks van om net die uitstaande positiewe gedrag ("dinge waarvan gehou is") en uitstaande negatiewe gedrag ("dinge waarop verbeter kon word") te noteer soos wat normaalweg die geval is.

Die gedrag is waargeneem deur alle verbale response wat in die vaardigheidsoefening tussen die twee rolspelers (een as toesighouer en een as ondergeskikte) uitgerui1 is, sistematies te noteer. Die tegniek wat gebruik is, is soortge1yk aan die gedragswaarnemingstegniek wat in bestuursbeoordelingsentrums (vergelyk Taft, 1955; Bray \& Grant, 1966) gebruik word. 
A1tesaam 1950 vaardigheidsoefeninge (130 dee1nemers x 5 verskillende interpersoonlike situasies x 3 vaardigheidsoefeninge per situasie per deelnemer) is oor 'n tydperk van vier maande tydens die aanbieding van die opleidingsessies waargeneem. Op hierdie wyse is 'n informasie-bank opgebou van 'n breë spektrum tipiese gedrag wat in die oefening van die leerpunte van die verskillende interpersoonlike situasies gemanifesteer is.

Die gedragsdata is in twee fases ontleed. Die eerste stap was om die data te inspekteer in 'n poging om breë klassifikasie kategorieë te ontwikke1 van die tipiese gedrag wat in die hantering van werkverwante interpersoonlike situasies gebruik word. Drie k1assifikasie kategorieë is ontwikkel:

Kategorie 1 - Gedrag wat in hierdie kategorie val is uitsluitlik daarop gemik om die tweede persoon (ondergeskikte, kliënt, ensovoorts) te ondersteun. Tipiese gedrag in kategorie 1 is nie-materiële beloning (vir goeie werk, uitnemende optrede, besondere bekwaamhede, mooi prestasies, ensovoorts) en hulpverlening. Kategorie 1 gedrag fasiliteer wedersydse vertroue, selfrespek en selfesteem.

Kategorie 2 - Gedrag wat in hierdie kategorie val is uitsluitlik daarop gemik om die tweede persoon (ondergeskikte, kliënt, ensovoorts) te akkommodeer. Tipiese gedrag in kategorie 2 is om die tweede persoon te betrek en aktief na sy probleme en standpunte te luister. Kategorie 2 gedrag fasiliteer wedersydse begrip en betrokkenheid.

Kategorie 3 - Gedrag wat in hierdie kategorie val is uitsluitlik daarop gemik om rigting te gee aan die verloop van die gesprek tussen die eerste persoon (toesighouer, leweransier, ensovoorts) en die tweede persoon (ondergeskikte, kliënt, ensovoorts). Tipiese gedrag in kategorie 3 is om onduidelikhede op te klaar, idees te gee, vordering op te som, verwante gesprekspunte saam te vat en opvolgaksies in te stel. Kategorie 3 gedrag verleen struktuur aan die gesprek tussen die eerste en die tweede persoon en fasiliteer gesamentlike problemoplossing.

Die tweede fase in die ontleding van die gedragsdata was om die verbale response in die drie breë kategorieë in te deel.

Die gedrag wat op hierdie wyse gekategoriseer is, is per kategorie vir gelyksoortigheid geïnspekteer in 'n poging om kleinere vaardigheidskomponente binne elke kategorie te identifiseer. Die vaardigheidskomponente word vervolgens per kategorie uiteengesit en aan die hand van tipiese verbale response beskryf:

Kategorie 1: Ondersteunende Gedrag (0) 
0.1 - gee erkenning/gee aanmoediging

"Dit is 'n goeie voorstel"; "Ek hou daarvan"; Ek weet jy kan dit doen"; "Jy is 'n man met goeie idees".

0.2 - gee ondersteuning

"Ek sal graag wil help"; "Ek gaan saam met jou voorstel”; "Ek sal dit vir jou doen";

"Om jou te help sal ek onderneem om ..."

Kategorie 2: Akkommoderende Gedrag (A)

A.1 - vra voorstelle/opinies

"Wat dink jy kan ons doen?" "Het jy enige idees of voorstelle hoe ons die probleem kan oplos?"; "Hoe voel jy hieroor?"; "Wat dink jy daarvan as ons dit so doen?".

\section{A.2 - toon begrip deur refleksie}

"Ek het nou na jou geluister en ek kry die gevoel jy is ongelukkig ... "; "As ek jou reg verstaan dan voel jy ... "; "So jy voel ons moet ... "

A.3 - skep geleentheid om te gesels

"Ek het 'n paar oomblikke as jy daaroor wil gesels"; "Gaan gerus aan ek luister"; "As jy tyd het, ek het tyd"; "As jy enige probleme het, kom na my"; "My deur staan oop vir jou"

Kategorie 3: Rigtingewende Gedrag (R)

R.1 - gee voorstelle/opinies

"Ek dink ons kan dit so doen"; "Een manier om die probleem op te los, is ... "; "Kom ons doen dit so ... "; "Ek wil voorstel ..."; "Wat ons moet doen is ..."

R.2 - vra opklaring

"Ek verstaan nie mooi nie, kan jy net weer verduidelik?"; "Wat bedoel jy presies met wat jy nou gesê het?"; "Hoekom dink jy het dit gebeur?".

R.3 - gee opklaring/samevatting

"Nee, dit is nie wat ek bedoel nie, ek bedoel ... "; "Laat ek weer verduidelik, net om

seker te maak jy verstaan"; "Om saam te vat ... "; "Om op te som ..." R.4 - stel keerdatum

"Dan gesels ons volgende week weer so teen hierdie tyd"; "Sal jy my oor 'n maand laat weet hoe jy vorder?"; "Ons moet teen môremiddag 3-uur met die taak klaar wees";

"Miskien sal dit goed wees as ons elke tweede dag kyk hoe sake verloop".

Deur hierdie proses van waarneming, ontleding en kategorisering is daar dan uitgekom by die gedragsvaardighede wat klaarblyklik onderliggend is aan die doeltreffende hantering 
van interpersoonlike situasies. Hoewel hierdie model van interpersoonlike doeltreffendheid, as dit so genoem kan word, op hierdie stadium slegs 'n konseptuele basis het, maak dit beslis aanspraak op logika en derhalwe het dit sekere implikasies vir gedragsmodeleringsopleiding. Die belangrikste implikasie is dat die tradisionele toepassingsterrein van die tegniek van gedragsmodelering, naamlik opleiding in interpersoonlike vaardighede, aansienlik gewysig (indien nie verbeter) kan word nie. Die aanpassing is daarin geleë dat daar in sodanige opleiding toegespits moet word op die aanleer van die gedragsvaardighede wat onderliggend is aan die leerpunte van interpersoonlike situasies eerder as op die leerpunte self. Op hierdie manier sal die leerling 'n breë repertoire van gedrag ontwikkel wat hom in staat sal stel om enige interpersoonlike situasie te hanteer. Hier is dan sprake van gedragsverbreding eerder as gedragsmodelering.

Heelwat navorsing sal gedoen moet word om die tegniek van gedragsverbreding empiries te fundeer. Die eerste stap moet wees om die konsep van gedragsverbreding as 'n opleidingstegnologie te operasionaliseer deur die model van interpersoonlike doeltreffendheid as basis van die tegnologie te gebruik.

\section{GEDRAGSVERBREDING}

Enige opleidingstegnologie moet op gesonde leerteorieë en leerbeginsels gebaseer wees. Die beginsels van verskeie leerteorieë, naamlik ervaringsleer (Bennis \& Shepard, 1956; Hampden-Turner, 1966) en sosiale leerteorie (Bandura, 1969; 1977) en verwante opleidingstegnieke naamlik rolspel (French, 1945) en gedragsontleding (Rackham \& Morgan, 1977) vorm die teoretiese grondslag van gedragsverbreding. Vervolgens word die beginsels wat van hierdie leerteoriëe en opleidingstegnieke ontleen is, maar meer spesifiek die manier waarop dit binne gedragsverbreding aangewend word, kortliks bespreek:

\section{Ervaringsleer}

Verskeie studies (Burke \& Bennis, 1961; Harrison, 1962; French, Sherwood \& Bradford, 1966; Peters, 1970) het aangetoon dat leer gefasiliteer word as die leerling insig in sy eie gedrag het. Hierdie beginsel word in gedragsverbreding gebruik deurdat 'n sensiteringsessie die vertrekpunt is van enige kursus wat hierdie opleidingstegnologie as onderbou het. In die sensiteringsessie hanteer die leerling 'n interpersoonlike situasie (rolspel) wat tipies is van die situasies waarop die gedragsverbredingsopleiding gemik is. 
$\mathrm{Na}$ afloop van die rolspel doen die leerling individuele nabetragting volgens bepaalde voorskrifte. In die nabetragting maak die leerling vir die eerste keer kennis met die breë gedragsvaardighede (ondersteunende gedrag, akkommoderende gedrag en rigtinggewende gedrag) en hoe dit in die hantering van die besondere situasie gebruik kan word om doeltreffendheid te verseker. Die leerling beoordeel sy eie hantering van die besondere interpersoonlike situasie deur hierdie vereistes en verkry sodoende insig in die vlak van sy interpersoonlike doeltreffendheid.

\section{Gedragsontleding}

Die model van interpersoonlike doeltreffendheid beklemtoon die aanwending van drie stelle gedragsvaardighede (0.1, 0.2; A.1, A.2, A.3; R.1, R.2, R.3, R.4) deur die gebruik van sekere vorms van verbale gedrag. Dit is derhalwe noodsaaklik dat daar in gedragsverbreding 'n sisteem gebruik word om verbale gedrag waar te neem. Die tegniek van gedragsontleding (Rackham \& Morgan, 1977) is vir hierdie doel gekies.

Wanneer gedrag in herkenningsoefeninge (teoretiese gespreksverloop en video-band rolspel) of in 'n vaardigheidsoefening (rolspel) tussen twee rolspelers uitgeruil word, word die frekwensie waarteen die verskillende gedragsvaardighede gebruik word, per kategorie (vaardigheid) genoteer. Spesifieke voorbeelde van gedrag word ook genoteer ten einde die frekwensiedata verder aan te vul. Die gedragsdata wat op hierdie manier ingesamel word, word tydens die herkenningsoefeninge gebruik om die leerling se konseptuele begrip van die gedragsvaardighede te versterk, terwyl dit in vaardigheidsoefening gebruik word om aan die leerling objektiewe terugvoering te gee oor die manier waarop hy die gedragsvaardighede in die hantering van die besondere situasie gebruik het.

\section{Rolspel}

Rolspel is een van die bekendste tegnieke wat in opleidingsituasies gebruik word om gedrag en houdings te verander. In toesighoueropleiding is dit waarskynlik die eerste keer deur French (1945) en Bradford en Lippitt (1940) gebruik. Sedertdien is heelwat navorsing gedoen om die effektiwiteit van die rolspel as houding- en gedragsveranderingstegniek te bepaal. Die oorgrote deel van hierdie navorsing (Janis \& King, 1954; King \& Janis, 1956; Mann, 1956; Scott, 1957; Scott, 1959; Shaw, 1959; Harvey \& Beverly, 1961; Zimbardo, 1965; Carlsmith, Collins \& Helmreich, 1966; Elms, 1967; McFall \& Marston, 1970) toon dat 
die rolspel 'n kragtige tegniek is om houdings en gedrag te verander, maar in die jongste verlede is die teendeel egter ook bewys deur navorsing wat Lichtenstein, Keutzer \& Himes (1969) en Ingersoll (1973) onderneem het.

Volgens Ingersoll (1973) lê die vermoë van die rolspeltegniek om permanente gedragsverandering teweeg te bring in die feit dat dit nie in samehang met ander gedragsveranderingstegnieke gebruik word nie, maar as 'n enkelvoudige metode. So byvoorbeeld kan gedragsverandering verwag word as die voordele van die gedrag wat in die rolspel geoefen word, aan die rolspeler uitgewys word. Dit kom dus daarop neer dat die rolspel nie as die enigste gedragsveranderingstegniek in opleiding gebruik moet word nie, maar in kombinasie met ander tegnieke aangewend moet word. In gedragsverbredingsopleiding is dit wat in effek gebeur. Rolspel word gebruik om die gedragsvaardighede $(0.1$, 0.2; A.1, A.2, A.3; R.1, R.2, R.4) in verskillende interpersoonlike situasies te oefen nadat dit teoreties deur die tegniek van gedragsontleding ingeskerp is.

\section{Sosiale leerteorie}

Die beginsel wat van die sosiale leerteorie (Bandura, 1969; 1977) ontleen is en inderdaad 'n belangrike komponent van gedragsverbreding uitmaak, is die proses van sosiale versterking. Sosiale versterking is daarop gemik om die voorkoms van gewensde gedrag in die toekoms te verseker. Hierdie vorm van versterking verskil van die tradisionele konsep van versterking in die sin dat dit uitsluitlik vanuit die sosiale omgewing afkomstig is. Erkenning, goedkeuring en aanvaarding is voorbeelde van sosiale versterking.

In volwasse leer is sosiale versterking volgens Zigler en Child (1969) baie meer effektief om gedragsverandering teweeg te bring as die tradisionele vorms van versterking en derhalwe word daar in gedragsverbredingsopleiding uitsluitlik van sosiale versterking gebruik gemaak. In gedragsverbredingsopleiding kry die leerling heelwat geleentheid om die drie stelle gedragsvaardighede in verskillende interpersoonlike situasies in die teenwoordigheid van medeleerlinge (wat binne opleidingsverband die sosiale omgewing uitmaak) te oefen. Tydens die rolspel (wat binne die konteks van gedragsverbreding as vaardigheidsoefening bekend staan), word die verbale gedrag van die leerling deur middel van die tegniek van gedragsontleding waargeneem en daarna word die waarnemings deur 'n proses van sosiale versterking aan die leerling teruggevoer. 
Uit die voorafgaade bespreking van die aanwending van sekere leerteorieë en opleidingstegnieke binne gedragsverbredingsopleiding is dit duidelik dat vyf leerprosesse in hierdie tipe opleiding gebruik word. Die leerprosesse met hul onderskeie leermikpunte en die leerteorie waaraan dit ontleen is, of die opleidingstegniek wat binne die besondere leerproses gebruik word, word vervolgens uiteengesit.

Sensiteringsproses (Ervaringsleer): Om die leerling insig in die doeltreffendheid van sy interpersoonlike gedrag te gee.

Herkenningsproses (Gedragsontleding): Om die leerling teoreties (teoretiese gespreksverloop en video-band) met die drie stelle gedragsvaardighede vertroud te maak deur die waarneming van die verbale gebruik van elke vaardigheid.

Oefening-proses (Rolspel): Om die leerling in staat te stel om die teoreties aangeleerde gedragsvaardighede prakties te oefen.

Waarnemingsproses (Gedragsontleding): Om die leerling prakties (rolspel) vertroud te maak met die drie stelle gedragsvaardighede deur die waarneming van die verbale gebruik van elke vaardigheid.

Versterkingsproses (Sosiale Leerteorie): Om die leerling se prakties aangeleerde gedrag sosiaal te versterk deur terugvoering van die verbale gebruik van die drie stelle gedragsvaardighede.

In gedragsverbredingsopleiding word hierdie vyf leerprosesse in hiërargiese orde aangewend sodat leer wat deur die een proses behaal word, deur die volgende proses versterk kan word. Hierdie leerstruktuur word skematies in Figuur 1 uiteengesit.

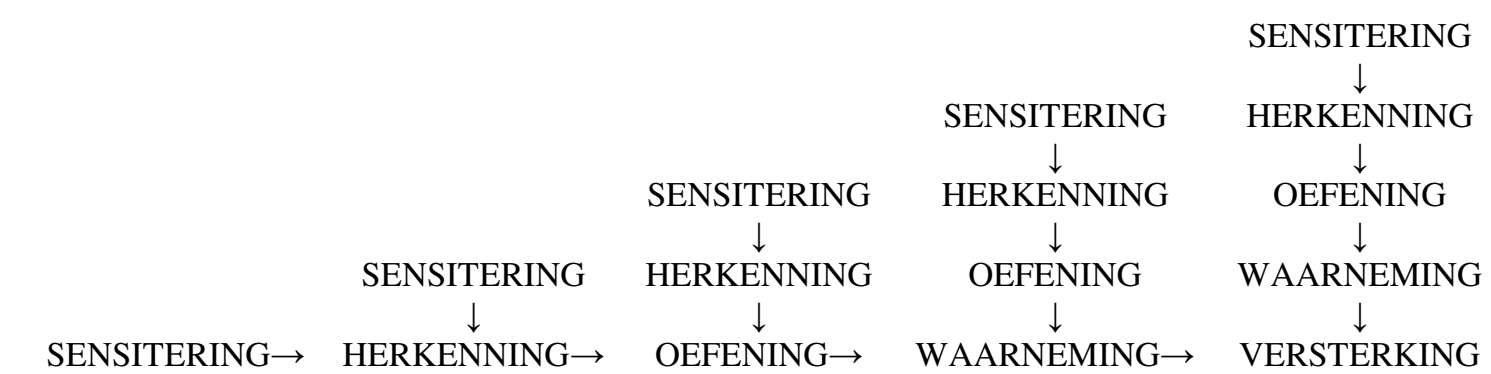

Figuur 1 : Die Leerstruktuur in Gedragsverbredingsopleiding

Op hierdie wyse is daar as eerste step operasionele gestalte gegee aan gedragsverbreding as opleidingstegnologie. Die volgende stap in die operasionalisering van gedragsverbreding was om 'n opleidingskursus volgens gedragsverbredingstegnologie te ontwikkel en dit dan eksperimenteel te toets. Dit sou dan die finale bewysplaas wees of 
gedragsverbredingsopleiding in staat is om gedragsverandering teweeg te bring. Op hierdie stadium het die skrywers die tegnologie nog net binne toesighoueropleiding aangewend en eksperimenteel getoets. Vervolgens word die kursus bespreek.

\section{DIE TOESIGHOUEROPLEIDINGSKURSUS}

Die kursus is ontwikkel om toesighouers in staat te stel om hul ondergeskiktes doeltreffend te hanteer. Hierdie opleidingsdoelwit het die breë verwysingsraamwerk gevorm vir die aanwending van die vyf leerprosesse in die kursus.

Die kursus begin deur die leerling geleentheid te gee om in die rol van toesighouer ' $n$ ondergeskikte (rol gespeel deur een van die kursusleiers) met 'n swak werksrekord te hanteer. Aan die einde van hierdie sessie doen die leerling individuele nabetragting. Hy doen dit deur die doeltreffendheid van sy eie optrede te beoordeel aan die hand van riglyne wat verskaf word met betrekking tot die gebruik van die breë gedragsvaardighede (ondersteunende gedrag, akkommoderende gedrag, rigtinggewende gedrag) binne die besondere interpersoonlike situasie wat hy pas hanteer het (Sensiteringsproses).

Hierna word die leerling op 'n teoretiese vlak vertroud gemaak met die model van interpersoonlike doeltreffendheid. Elke stel gedragsvaardighede word afsonderlik geneem en by die leerling ingeskerp. Dit word gedoen deur ' $n$ stel vaardighede deur middel van 'n teoretiese inset aan die leerlinge bekend te stel en hulle onmiddellik daarna die geleentheid te gee om die gebruik van daardie vaardighede in tipiese toesighouer-ondergeskikte situasies (byvoorbeeld die hantering van 'n klagte, die oplossing van 'n probleem, die gee van 'n instruksie, ensovoorts) te herken. Twee tipes herkenningsoefeninge word vir hierdie doel gebruik, naamlik 'n teoretiese gespreksverloop (op papier) en 'n videoband rolspel (gesimuleerd). In die teoretiese gespreksverloop moet die leerling die gebruik van 'n besondere stel gedragsvaardighede identifiseer en in die video-band rolspel moet die leerling dit weer waarneem (Herkenningsproses).

Nadat die drie stelle vaardighede deur die voorafgaande proses teoreties ingeprent is, word daar in die kursus oorgegaan tot die oefening van die drie stelle gedragsvaardighede in verskillende tipiese toesighouer-ondergeskikte situasies. Hierdie deel van die kursus is baie intensief aangesien oefening vermoedelik die grootste bydrae lewer tot die internalisering van die gedragsvaardighede. Die leerling word nie, soos wat dikwels die geval is (vergelyk Byham, Adam en Kiggins, 1976), net een of twee geleenthede gegee om die gedragsvaardig- 
hede te oefen nie, maar word inderdaad verskeie geleenthede gebied om die nuut aangeleerde vaardighede in tipiese toesighouer-ondergeskikte situasies te oefen (Oefening-proses).

In die oefening-proses word die leerling se gebruik van die drie stelle gedragsvaardighede deur sy mede-leerlinge en die opleier waargeneem. Hoewel daar hoofsaaklik gekyk word na die verbalisering van die verskillende gedragsvaardighede, word nie-verbale gedrag (liggaamstaal) ook in ag geneem (Waarnemingsproses).

Deur hierdie proses van waarneming word daar ten opsigte van 'n leerling se hantering van 'n besondere toesighouer-ondergeskikte situasie heelwat gedragsdata ingesamel wat die basis vorm vir die terugvoering wat na afloop van die oefensessie gedoen word. Die terugvoering voorsien die leerling van objektiewe inligting oor sy gebruik van die gedragsvaardighede. Positiewe gedrag word versterk deur sosiale vorms van beloning en negatiewe gedrag word afgebreek deur sosiale vorms van aanmoediging om te verbeter (Versterkingsproses).

Die kursus strek oor drie en 'n half dae en beloop bykans 40 uur opleidingstyd. Hieruit kan afgelei word dat die kursus op die beginsel van massa-leer en nie op die beginsel van gespasieerde-leer gebaseer is nie. As laasgenoemde beginsel gebruik sou word, sou dit daarop neergekom het dat die aanbieding van die kursus in logiese gedeeltes oor 'n sekere tydperk (sê een dag per maand vir vier maande) versprei word. Die probleem met hierdie metode is dat dit die internalisering van nuwe gedrag belemmer en derhalwe is daar op die beginsel van massaleer besluit. Die aanvanklike kursus word egter na verloop van 'n paar maande met half-dag sessies opgevolg om probleme met die gebruik van die gedragsvaardighede in die werksituasie (oordrag van leer met ander woorde) uit te stryk. Op hierdie wyse word daar dan tog in 'n sekere mate van die beginsel van gespasieërde-leer gebruik gemaak.

Die vermoë van hierdie kursus om toesighouers in staat te stel om ondergeskiktes doeltreffend te hanteer, is in 'n eksperimentele studie geëvalueer.

\section{DIE EKSPERIMENTELE STUDIE}

\section{Verloop van die studie}

Die studie het oor agt maande gestrek. Sestig toesighouers het gedurende die eerste twee maande die gedragsverbredingsopleiding ondergaan. Ses kursusse is aangebied en tien toesighouers is per kursus opgelei. Na verloop van ses maande is die proefpersone in dieselfde 
orde waarin hulle die kursusse bygewoon het, by 'n diverse opleidingsprogram betrek. Die eerste dag van hierdie program is as 'n evalueringsessie gebruik.

\section{Eksperimentele Ontwerp}

Vanweë verskeie praktiese oorwegings kon daar nie van 'n suiwer eksperimentele ontwerp gebruik gemaak word om die effek van die gedragsverbredingsopleiding te evalueer nie en derhalwe is 'n kwasi-eksperimentele ontwerp gekies. Die verdeelde groep voortoetsnatoets ontwerp ("separate-sample pretest-posttest design") (vergelyk Campbell \& Stanley, 1963), is gebruik. In hierdie ontwerp word eksperimentele kontrole deur die gebruik van ewekansige steekproeftrekking verkry. Die ontwerp word diagrammaties in Figuur 2 voorgestel.

Figuur 2 : Die verdeelde groep voortoets-natoets antwerp

In die diagram verteenwoordig $R_{1}$ en $R_{2}$ twee ewekansige subgroepe, $0_{1}$ is ' $n$ voormeting van die een subgroep $\left(\mathrm{R}_{1}\right)$ en $0_{2}$ is 'n nameting van die ander subgroep $\left(\mathrm{R}_{2}\right)$. $X$ verteenwoordig die eksperimentele veranderlike (in hierdie geval die gedragsverbredingsopleiding). Een subgroep (in hierdie geval $\mathrm{R}_{1}$ ) word voor die toepassing van die eksperimentele veranderlike gemeet en die ander subgroep (in hierdie geval $\mathrm{R}_{2}$ ) word na die toepassing gemeet.

Deur die gebruik van hierdie ontwerp in die onderhawige studie, is die proefgroep (60 toesighouers) in twee ewekansige subgroepe (30 toesighouers elk) verdeel. Die een subgroep (hierna genoem V-subgroep) is gebruik vir die insameling van voormetings, terwyl die ander subgroep (hierna genoem $\mathrm{N}$-subgroep) gebruik is vir die insameling van nametings. Soos die diagram in Figuur 2 aandui het al die proefpersone (met ander woorde sowel die V-subgroep as die $\mathrm{N}$-subgroep) gedragsverbredingsopleiding ondergaan, maar slegs die V-subgroep is vooraf gemeet en slegs die N-subgroep is na afloop van die opleiding gemeet. Dit bring ons dan by die vlak waarop die evaluering gemik was en die meetinstrumente wat gebruik is om die evalueringsdata in te samel. 


\section{Evalueringsvlak}

Opleiding kan volgens Kirkpatrick (1979) op vier vlakke geëvalueer word, naamlik reaksie, leer, gedrag en resultate. In hierdie studie is gedragsverbredingsopleiding op ' $n$ gedragsvlak geëvalueer in die sin dat die toesighouer se hantering van 'n gesimuleerde werkverwante situasie voor en na die kursus vergelyk is. Op hierdie wyse kan 'n verandering in werksgedrag, hoewel indirek vanweë die gesimuleerde situasie, gemeet word. Daar is verder ook gekyk of die toesighouer se houding teenoor die hantering van ondergeskiktes deur gedragsverbredingsopleiding verander word. Dit is gedoen deur die toesighouer se houding teenoor die twee welbekende vorms van leierskapgedrag, naamlik konsiderasie ("consideration") en taakstrukturering ("inisiating structure") (Fleishman, 1953), voor en na die gedragsverbredings-opleiding te meet en te bepaal of dit beduidend verander (verhoog) het.

\section{Meetinstrumente}

Twee meetinstrumente is gebruik om die evalueringsdata in te samel, naamlik die beoordelingsentrum (vergelyk Taft, 1955; Bray \& Grant, 1966; Byham \& Thornton, 1970) en die Leadership Opinion Questionnaire (Fleishman, 1960).

\section{Beoordelingsentrum}

Die beoordelingsentrum berus op die beginsel van meervoudige beoordeling, met ander woorde, die gedrag wat 'n individu in verskillende situasies (gesimuleerd) openbaar, word deur verskillende assessore waargeneem en beoordeel. Die tegniek word veral gebruik om bestuurs- en toesighouerspotensiaal te identifiseer (Dicken \& Black, 1965; Byham, 1970).

In die onderhawige studie is die beoordelingsentrumtegniek, hoewel in 'n effens ander gedaante, gebruik om in 'n gesimuleerde situasie te bepaal hoe doeltreffend die toesighouer sy ondergeskikte hanteer. Daar moes vanweë die hoë koste van opleidingstyd noodgedwonge weggebreek word van meervoudige situasies, maar daar is tog daarvoor probeer kompenseer deur die gesimuleerde situasie "meervoudig" te maak. Dit is gedoen deur aan die rolspeler opdrag te gee om benewens die rol wat hy volgens die leerling se instruksies moet vertolk, naamlik die van 'n ondergeskikte met 'n swak diensrekord wat al weer 'n misstap begaan het, ook 'n aantal klagtes te opper en voorstelle te maak. Op hierdie manier kon bepaal word of die toesighouer in staat is om verskillende "momente" binne dieselfde situasie te hanteer. 
Die toesighouer se hantering van die ondergeskikte in hierdie gesimuleerde situasie is deur ' $n$ paneel van drie persone, wat deeglik vertroud is met die beoordelingsentrumtegniek, waargeneem en beoordeel. Elke paneellid het die toesighouers na waarneming van die situasie individueel aangeslaan ten opsigte van die doeltreffendheid waarmee die situasie hanteer is en daarby is die gebruik van die drie breë gedragsvaardighede (ondersteunende gedragsvaardighede, akkommoderende gedragsvaardighede, rigtinggewende gedragsvaardighede) ook beoordeel. Na die individuele beoordeling het die paneel hul beoordelings gepoel, dit bespreek en op 'n konsensuspunt vir elke besondere aspek besluit.

Ses maande na afloop van die gedragsverbredingsopleiding is die leerling binne soortgelyke omstandighede beoordeel. Hierdie sessie het deel uitgemaak van 'n diverse opleidingsprogram wat vir die proefpersone aangebied is en derhalwe was hulle nie daarop voorbereid nie. Hierdie evaluering is op dieselfde manier as die eerste evaluering gedoen. Die enigste verskil was dat 'n ander interpersoonlike situasie, hoewel nog steeds werkgebonde en "meervoudig", gebruik is om die leerling (toesighouer) se vermoë te beoordeel om sy ondergeskikte te hanteer.

Hoewel al die proefpersone beoordeel is op die manier wat hierbo beskryf is, is slegs die voorbeoordelings van die $\mathrm{V}$-subgroep en die nabeoordelings van die $\mathrm{N}$-subgroep vir evalueringsdoeleindes gebruik.

\section{Leadership Opinion Questionnaire}

In leierskapnavorsing wat oor die afgelope dertig jaar onderneem is, is daar hoofsaaklik van twee vraelyste gebruik gemaak, naamlik die Leader Behaviour Description Questionnaire (LBDQ) wat deur Hemphill en Coons (1957) ontwikkel is en die Leadership Opinion Questionnaire (LOQ) wat in dieselfde jaar deur Fleishman (1960) ontwikkel is. Die twee vraelyste meet dieselfde konstrukte naamlik konsiderasie ("consideration") en taakstrukturering ("initiating structure"), maar verskil wel ten opsigte van respondent. Die LBDQ word deur die toetsling (toesighouer of bestuurder) se ondergeskiktes ingevul, terwyl die LOQ deur die toetsling self voltooi word.

In die onderhawige studie is die LOQ gebruik omdat dit in die betrokke organisasie waar die studie uitgevoer is, nie sosiaal aanvaarbaar is dat ondergeskiktes 'n waarde-oordeel oor meerderes vel nie. 'n Verdere rede is dat die LOQ skynbaar in navorsing met groter sukses as die LBDQ gebruik word. 'n Geweldige hoeveelheid navorsingsbevindings is sedert die 
vyftigerjare deur die gebruik van die LOQ en LBDQ opgebou (vergelyk Korman, 1966; Fleishman, 1973; Vroom, 1976). Hoewel die resultate ietwat inkonsekwent is (Vroom, 1976; Saha, 1979), is die beste geldigheidskoëffisiënte in studies gevind waarin die LOQ gebruik is (Korman, 1968).

'n Ander belangrike voordeel van die LOQ is dat die subvelde ("consideration" en "initiating structure") onbeduidende interkorrelasies met mekaar toon. De Bod (1980) rapporteer interkorrelasies van $\mathrm{r}(28)=, 14 ; \mathrm{r}(28)=, 28$ en $\mathrm{r}(58)=, 09$ synde die verwantskap tussen die twee subvelde van die LOQ soos toegepas op drie proefgroepe.

Hoewel al die proefpersone in die onderhawige studie voor die aanvang van die gedragsverbredingsopleiding en weer ses maande daarna gevra is om die LOQ te voltooi, is slegs die V-subgroep se tellings as voorafmeting en slegs die $\mathrm{N}$-subgroep se tellings as nameting gebruik.

\section{Verwerking van gegewens}

Die data wat deur bogenoemde twee meetinstrumente ingesamel is, is statisties ontleed om te bepaal of gedragsverbredingsopleiding enigsins in staat is om gedrag beduidend te verander.

Data wat deur die gebruik van die beoordelingsentrumtegniek ingesamel is, is met behulp van 'n t-toets-tegniek (verwysingsnota 1) ontleed om te bepaal of die toesighouer sy ondergeskikte in 'n gesimuleerde werksituasie meer effektief na gedragsverbredingsopleiding hanteer. Soortgelyke ontledings is gedoen om te bepaal of die toesighouer se gebruik van die drie breë gedragsvaardighede na die opleiding verbeter het. Terselfdertyd is die interbeoordelaarbetroubaarheid van die beoordelingspaneel deur middel van interkorrelasie-berekeninge (verwysingsnota 1) bepaal in 'n poging om die resultate van hierdie besondere gedeelte van die studie, meer sinvol te interpreteer.

Data wat deur die gebruik van die LOQ ingesamel is, is ook met behulp van 'n t-toetstegniek (verwysingsnota 1) ontleed om te bepaal of die toesighouer se bestuursoriëntasie as gevolg van gedragsverbredingsopleiding meer konsidererend en meer strukturerend geword het. 
Voordat die opleiding 'n aanvang geneem het, is die twee subgroepe (V-subgroep en Nsubgroep) vir homogeniteit getoets ten opsigte van ouderdom, taal en opvoedkundige kwalifikasies. Dit is gedoen deur die beduidendheid van die verskille tussen die twee subgroepe se gemiddeldes op hierdie drie veranderlikes met behulp van 'n t-toets te bepaal. Die beskrywende statistiek vir die drie veranderlikes en die berekende t-waardes word onderskeidelik in Tabel 1 en Tabel 2 aangetoon.

\section{$\underline{\text { TABEL } 1}$}

BESKRYWENDE STATISTIEK TEN OPSIGTE VAN DIE V-SUBGROEP (N=30) EN N-SUBGROEP (N=30) SE OUDERDOM, TAAL EN OPVOEDKUNDIGE KWALIFIKASIES

\begin{tabular}{|l|c|c|c|c|c|c|c|c|}
\hline & \multicolumn{2}{|c|}{ GEMIDDELDE } & \multicolumn{2}{c|}{$\begin{array}{c}\text { STANDAARD- } \\
\text { AFWYKING }\end{array}$} & \multicolumn{2}{c|}{ SKEEFHEID } & \multicolumn{2}{c|}{ KURTOSE } \\
\cline { 2 - 9 } & $\begin{array}{c}\text { V- } \\
\text { GROEP }\end{array}$ & $\begin{array}{c}\text { N- } \\
\text { GROEP }\end{array}$ & $\begin{array}{c}\text { V- } \\
\text { GROEP }\end{array}$ & $\begin{array}{c}\text { N- } \\
\text { GROEP }\end{array}$ & $\begin{array}{c}\text { V- } \\
\text { GROEP }\end{array}$ & $\begin{array}{c}\text { N- } \\
\text { GROEP }\end{array}$ & $\begin{array}{c}\text { V- } \\
\text { GROEP }\end{array}$ & $\begin{array}{c}\text { N- } \\
\text { GROEP }\end{array}$ \\
\hline OUDERDOM & 46,80 & 46,84 & 7,91 & 7,34 &,- 44 &,- 62 &,- 49 &,- 42 \\
TAAL & 1,36 & 1,36 &, 49 &, 49 &, 58 &, 58 & $-1,66$ & $-1,66$ \\
OPVOED- & & & & & & & & \\
KUNDIGE & & & & & & & & \\
KWALIFI- & & & & & & & & \\
KASIE & 8,20 & 7,84 & 1,04 & 0,79 & 0,27 & 0,59 &,- 23 &,- 03 \\
\hline
\end{tabular}

\section{TABEL 2}

t-WAARDES TEN OPSIGTE VAN DIE VERSKIL TUSSEN DIE V-SUBGROEP ( $=30)$ EN N-SUBGROEP (N=30) SE GEMIDDELDE OUDERDOM, TAAL EN OPVOEDKUNDIGE KWALIFIKASIES

\begin{tabular}{|l|c|c|}
\hline & t-WAARDES & BEDUIDENHEIDSPEIL \\
\hline OUDERDOM &,- 9646 & ONBD. \\
TAAL &, 0000 & ONBD. \\
OPVOEDKUNDIGE & & \\
KWALIFIKASIE & 1,2810 & ONBD. \\
\hline
\end{tabular}

Uit hierdie ontleding is die afleiding gemaak dat die twee subgroepe homogeen is en dat die insameling van die evaluerings-data maar kan voortgaan. Dit is gedoen deur twee 
toepassings (voor opleiding en ses maande na opleiding) van die meetinstrumente wat in die voorafgaande gedeelte beskryf is.

Die beoordelingsentrumtegniek is gebruik om die doeltreffendheid te beoordeel waarmee die toesighouer 'n werkverwante interpersoonlike situasie hanteer en om te bepaal of die vlak van hul gedragsvaardighede deur die gedragsverbredingsopleiding verhoog is. ' $n$ Belangrike oorweging by die statistiese verwerking van die beoordelingsdata, was dat die interbeoordelaarbetroubaarheid hoog moet wees. Dit is bepaal deur die interkorrelasies tussen die beoordelaars se beoordeling van die algehele doeltreffendheid van die toesighouer se hantering van die interpersoonlike situasie en die gedragsvaardighede te bereken.

Die gemiddelde betroubaarheidskoëffisiënt vir die voorbeoordeling was ,92 met die laagste koëffisiënt, 84 en die hoogste, 97 . Vir die nabeoordelings was die gemiddelde koëffisiënt ,84 met die hoogste en laagste koëffisiënte onderskeidelik ,90 en ,76. Hierdie betroubaarheidskoëffisiënte is uit 'n statistiese oogpunt op 'n aanvaarbare vlak en derhalwe is daar voortgegaan met die ontleding van die beoordelingsdata.

Die beduidendheid van die verskil tussen die gemiddeldes van die twee subgroepe op die vier beoordelingsdimensies (algehele doeltreffendheid, ondersteunende gedrag, akkommoderende gedrag, rigtinggewende gedrag) is met behulp van die t-toetstegniek bepaal. In Tabel 3 word beskrywende statistiek ten opsigte van die vier beoordelingsdimensies vir die $\mathrm{V}$-subgroep en N-subgroep gegee, terwyl die berekende t-waardes in Tabel 4 aangetoon word.

\section{TABEL 3}

BESKRYWENDE STATISTIEK TEN OPSIGTE VAN DIE V-SUBGROEP (N=30) EN NSUBGROEP $(\mathrm{N}=30)$ SE BEOORDELINGS VAN ALGEHELE DOELTREFFENDHEID, ONDERSTEUNENDE GEDRAG, AKKOMMODERENDE GEDRAG EN RIGTINGGEWENDE GEDRAG

\begin{tabular}{|c|c|c|c|c|c|c|c|c|}
\hline & \multicolumn{2}{|c|}{ GEMIDDELDE } & \multicolumn{2}{|c|}{$\begin{array}{l}\text { STANDAARD- } \\
\text { AFWYKING }\end{array}$} & \multicolumn{2}{|c|}{ SKEEFHEID } & \multicolumn{2}{|c|}{ KURTOSE } \\
\hline & \begin{tabular}{|c|} 
V- \\
GROEP
\end{tabular} & \begin{tabular}{|c|}
$\mathrm{N}-$ \\
GROEP
\end{tabular} & $\begin{array}{c}\mathrm{V}- \\
\text { GROEP }\end{array}$ & $\begin{array}{c}\mathrm{N}- \\
\text { GROEP }\end{array}$ & $\begin{array}{c}\text { V- } \\
\text { GROEP }\end{array}$ & $\begin{array}{c}\mathrm{N}- \\
\text { GROEI }\end{array}$ & $\begin{array}{c}\text { V- } \\
\text { GROEP }\end{array}$ & $\begin{array}{c}\mathrm{N}- \\
\text { GROEP }\end{array}$ \\
\hline ALGEHELE DOEL- & & & & & & & & \\
\hline $\begin{array}{l}\text { TREFFENDHEID } \\
\text { ONDERSTEUNENDE }\end{array}$ & 3,08 & 4,28 & 1,68 & 1,54 &,- 07 &,- 83 & $-1,65$ &,- 39 \\
\hline $\begin{array}{l}\text { GEDRAG } \\
\text { AKKOMMODERENDE }\end{array}$ & 2,28 & 4,28 & 1,34 & 1,28 & ,86 &,- 54 &,- 32 &,- 57 \\
\hline $\begin{array}{l}\text { GEDRAG } \\
\text { RIGTINGGEWENDE }\end{array}$ & 2,72 & 4,76 & 1,52 & 1,45 &, 56 &,- 99 &,- 84 &, 07 \\
\hline GEDRAG & 2,28 & 4,48 & 1,37 & 1,45 & ,87 &,- 38 &,- 45 & $-1,21$ \\
\hline
\end{tabular}




\section{TABEL 4}

t-WAARDES TEN OPSIGTE VAN DIE VERSKIL TUSSEN DIE V-SUBGROEP ( $\mathrm{N}=30)$ EN N-SUBGROEP (N=30) SE GEMIDDELDE ALGEHELE DOELTREFFENDHEID, ONDERSTEUNENDE GEDRAG, AKKOMMODERENDE GEDRAG EN RIGTINGGEWENDE GEDRAG

\begin{tabular}{|c|c|c|}
\hline & t-WAARDES & $\begin{array}{l}\text { BEDUIDENHEIDS- } \\
\text { PEIL }\end{array}$ \\
\hline $\begin{array}{l}\text { ALGEHELE DOELTREF- } \\
\text { FENDHEID }\end{array}$ & $-2,6846$ & $1,0 \%$ \\
\hline $\begin{array}{l}\text { ONDERSTEUNENDE } \\
\text { GEDRAG }\end{array}$ & $-5,5189$ &, $1 \%$ \\
\hline $\begin{array}{l}\text { AKKOMMODERENDE } \\
\text { GEDRAG }\end{array}$ & $-4,9629$ &, $1 \%$ \\
\hline $\begin{array}{l}\text { RIGTINGGEWENDE } \\
\text { GEDRAG }\end{array}$ & $-5,6346$ &, $1 \%$ \\
\hline
\end{tabular}

$\mathrm{Al}$ vier die beoordelingsdimensies het beduidende verskille tussen die twee subgroepe getoon. Hieruit kan afgelei word dat gedragsverbredingsopleiding 'n wesenlike rol gespeel het in die doeltreffendheid waarmee toesighouers 'n werkverwante interpersoonlike situasie hanteer. Terselfdertyd het die toesighouers 'n breë repertoire van gedrag ontwikkel in die sin dat hulle in die hantering van die interpersoonlike situasie baie meer van ondersteunende, akkommoderende en rigtinggewende gedrag gebruik gemaak het.

Die data wat deur die toepassing van die Leadership Opinion Questionnaire verkry is, het betrekking op die toesighouer se taak- en mensoriëntasie ("initiating structure" en "consideration") Vooraf is gehipotetiseer dat gedragsverbreding beide oriëntasies sal verhoog. Hierdie hipotese is ook met behulp van 'n t-toets getoets. Die gemiddelde tellings wat die Vsubgroep en die N-subgroep op die twee oriëntasies behaal het, asook die standaardafwykings en t-waardes word in Tabel 5 aangetoon. 


\section{TABEL 5}

GEMIDDELDES, STANDAARDAFWYKING EN t-WAARDES TEN OPSIGTE VAN DIE V-SUBGROEP $(\mathrm{N}=30)$ EN N-SUBGROEP $(\mathrm{N}=30)$ SE MENS- EN TAAKORIËNTASIE SOOS GEMEET DEUR DIE LEADERSHIP OPINION QUESTIONNAIRE

\begin{tabular}{|l|c|c|c|c|c|c|}
\hline & \multicolumn{2}{|c|}{ GEMIDDELDE } & \multicolumn{2}{c|}{$\begin{array}{c}\text { STANDAARDAF- } \\
\text { WYKING }\end{array}$} & \multirow{2}{*}{$\begin{array}{c}\mathrm{t}- \\
\text { W- }\end{array}$} & $\begin{array}{c}\text { BEDUIDEND- } \\
\text { HEIDSPEIL }\end{array}$ \\
\cline { 2 - 5 } & $\begin{array}{c}\text { V- } \\
\text { GROEP }\end{array}$ & $\begin{array}{c}\text { N- } \\
\text { GROEP }\end{array}$ & $\begin{array}{c}\text { V- } \\
\text { GROEP }\end{array}$ & $\begin{array}{c}\text { N- } \\
\text { GROEP }\end{array}$ & WAARDES & HAEn \\
\hline $\begin{array}{l}\text { MENSORIËNTASIE } \\
\text { "CONSIDERATION" }\end{array}$ & 43,44 & 47,44 & 5,90 & 4,72 & 3,51 &, $1 \%$ \\
$\begin{array}{l}\text { TAAKORIËNTASIE } \\
\text { ("INITIATING } \\
\text { STRUCTURE") }\end{array}$ & 44,60 & 47,12 & 6,59 & 5,70 & $-2,05$ & $5,0 \%$ \\
\hline
\end{tabular}

Uit tabel 5 kan afgelei word dat gedragsverbreding daarin slaag om toesighouers se mens- en taakoriëntasie beduidend te verhoog. Hierdie bevinding het bepaalde implikasies vir tradisionele ruitekaart opleiding. In hierdie tipe opleiding (Blake \& Mouton, 1968; Reddin, 1968) word die leerling insig in sy eie bestuursoriëntasie gegee deur 'n model van tipiese oriëntasies of style aan hom voor te hou. Die rasionaal is dat hierdie proses tot 'n verhoging van beide oriëntasies sal lei. In die literatuur (Campbell \& Dunnette, 1969; Campbell, Dunnette, Lawler \& Weick, 1970; Bowers, 1973; Kahn, 1974) bestaan daar egter ernstige bedenkinge of hierdie doelwitte wel behaal word. Die resultate van hierdie studie dui daarop dat die gebruik van gedragsverbredingstegnologie in hierdie tipe opleiding gebruik kan word om 'n toesighouer of bestuurder se taak- en mensoriëntasie te verhoog.

\section{GEVOLGTREKKINGS EN AANBEVELINGS}

Dit sou onwetenskaplik (en weliswaar ook voorbarig) wees om op grond van die resultate van hierdie studie ongekwalifiseerd te beweer dat gedragsverbreding ' $n$ besonder kragtige opleidingstegnologie is. Die belangrikste rede vir 'n versigtige benadering is die feit dat daar in die studie nie van 'n kontrole groep in die tradisionele sin van die woord gebruik gemaak is nie. Daar is wel deur ewekansige steekproeftrekking en homogeniteitstoetsing vir kansfaktore probeer kontroleer, maar ten opsigte van sodanige eksperimentele suiwering is daar steeds in die ontwerp ruimte vir ongekontroleerde variansie. 
Ondanks hierdie beperkinge is die resultate oortuigend genoeg om ten minste met redelike sekerheid die afleiding te maak dat gedragsverbreding veel belofte as opleidingstegnologie inhou.

Hiermee word nie daarop aanspraak gemaak dat gedragsverbreding iets uniek is nie, dit wil ook nie sê dat gedragsverbreding 'n oplossing is vir al wat 'n opleidingsprobleem is nie. Gedragsverbreding is egter ongetwyfeld lewensvatbaar, eenvoudig dog wetenskaplik en het die potensiaal om gedragsverandering teweeg te bring.

In hierdie studie is die konsep van gedragsverbredingteoreties omlyn. Die komponente van gedragsverbredingsopleiding is bespreek deur dit aan bestaande leerteorieë en opleidingstegnieke te koppel. Daarna is probeer om gedragsverbreding te operasionaliseer deur die onderliggende tegnologie te gebruik om 'n kursus vir toesighouers te ontwikkel en dit empiries te evalueer. Op hierdie stadium dui die resultate daarop, al is dit dan net voorlopig, dat met gedragsverbreding as opleidingstegnologie interpersoonlike doeltreffendheid verhoog kan word.

Veel meer navorsing sal egter gedoen moet word om gedragsverbreding as opleidingstegnologie te operasionaliseer. Hier word byvoorbeeld gedink aan navorsing met betrekking tot die verskillende leerkomponente (sensitering, herkenning, oefening, waarneming, versterking) van gedragsverbredingsopleiding. Verder moet opleidingskursusse wat soortgelyk is aan die een wat in hierdie studie beskryf is, op grond van die tegniek van gedragsverbreding ontwikkel en geëvalueer word. Verskeie opwindende opsies vir verdere toepassing van die tegniek is oop, veral vanweë die feit dat die leerling in gedragsverbredingsopleiding aanleer om positiewe gedrag op 'n natuurlike wyse te demonstreer en uit te leef, pleks van om positiewe gedrag bloot na te boots. Hierdie besondere kenmerk van gedragsverbredingsopleiding maak dit uiters geskik vir gebruik oor 'n wye spektrum werksoorte.

\section{OPSOMMING}

Gedragsverbreding is 'n opleidingstegnologie wat spesifiek ontwikkel is om die toesighouer in staat te stel om doeltreffend in verskillende situasies op te tree. Die tegnologie word konseptueel beskryf deur dit aan bestaande leerteorieë en opleidingstegnieke te koppel. Daarna word 'n eerste poging aangewend om dit te operasionaliseer deur 'n gedragverbredingskursus te ontwikkel en eksperimenteel te evalueer ( $N=60$ toesighouers). Die resultate toon dat die toesighouers deur die gedragsverbredingsopleiding in staat is om interpersoonlike situasies meer doeltreffend te 
hanteer, 'n brë̈ repertoire van gedrag ontwikkel en 'n hoër mate van taak- en mensgerigtheid openbaar.

\section{VERWYSINGS}

Albers, H.H. Principles of Management: A Model Approach. New York: John Wiley and Sons, 1969.

Albrecht, F. $\quad$ Rasse-eksperiment kan wêreld aan brand steek. Rapport, 14 Desember 1980, 3.

Alderfer, C.P. An empirical test of a new theory of human needs. Organizational Behavior and Human Performance, 1969, 4, 142-175.

Backer, W. Motivating Black Workers. Johannesburg: McGraw-Hill, 1973.

Bandura, A. Principles of Behavior Modification. New York: Holt, Rinehart and Winston, 1969.

Bandura, A. Social Learning Theory. Englewood Cliffs, New Jersey: Prentice Hall, 1977.

Bennis, W.G. \& Shephard, H.A. A theory of group development. Human Relations, 1956, 9, 415-437.

Blackler, F. \& Williams, R. Peoples' motives at work. In Warr, P.B. (Red.) Psychology at Work. Harmandsworth, Middlesex: Penguin Books, 1971.

Bowers, D.G. O.D. techniques and their results in 23 organizations, Journal of Applied Behavioral Science, 1973, 9, 21-42.

Bradford, L.P. \& Lippitt, R. Role-playing in supervisory training, Personnel, 1946, 22, 358369.

Bray, D.W. \& Grant, D.L. The assessment centre in the measurement of business potential for business management, Psychological Monographs, 1966, 80, (17, whole No. 625), $1-27$.

Burke, R.L. \& Bennis, W.G. Changes in perceptions of self and others during human relations training, Human Relations, 1961, 14, 165-182.

Burnaska, R.F. The effects of behavior modeling training upon managers' behaviours and employees' perceptions. Personnel Psychology, 1976, 29, 29-335.

Burns, T. Management in action. Operational Research Quarterly, 1957, 8, 45-60.

Byham, W.C. Assessment centres for spotting future managers. Harvard Business Review, 1972, 48, 150-160, 162-165.

Byham, W.C. \& Thornton III, G.C. Assessment centres: A new aid in management selection. Studies in Personnel Psychology, 1970, 2, 21-31.

Byham, W.C., Adams, D. \& Kiggins, A. Transfer of modeling training to the job. Personnel Psychology, 1976, 29, 345-349.

Campbell, D.T. \& Stanley, J.C. Experimental and Quasi-experimental Designs for Research. Chicago: Rand McNally, 1963.

Campbell, J.P. \& Dunnette, M.D. Effectiveness of T-group experiences in managerial training and development. Psychological Bulletin, 1968, 70, 73-104.

Campbell, J.P., Dunnette, M.D., Lawler, E.E. \& Weick, K.E. Managerial Behavior, Performance and Effectiveness. New York: McGraw-Hill, 1970.

Carlsmith, J.M., Collins, B.E. \& Helmreich, R.K. Studies in forced compliance: 1. The effect of pressure for compliance on attitude change produced by face-to-face role playing and anonymous essay writing. Journal of Personality and Social Psychology. 1966, 4, 1-13.

Connor, P.E. Dimensions in Modern Management. Boston: Houghton Mifflin, 1978.

Copeman, G., Luijk, H. \& Hanika, F. de P. How the Executive Spends his Time. London: Business Publications, 1963. 
Davis, R.C. Industrial Organization and Management. New York: Harper and Row, 1940.

De Bod, A.D. Tydoriëntasie as ' $n$ fundamentele konsep in bestuursgedrag en bestuurstalent. Ongepubliseerde Magister Verhandeling. Randse Afrikaanse Universiteit, 1980.

Dicken, P.J. Effects of symbolic coding and rehearsal in behavior-modeling training. Journal of Applied Psychology, 1980, 65, 627-634.

Dicken, C.F. \& Black, J.D. Predictive validity of psychometric evaluations of supervisors. Journal of Applied Psychology, 1965, 49, 34-37.

Elms, A.C. Role playing, incentive and dissonance. Psychological Bulletin. 1967, 63, 132148.

Fayol, H. Administration Indistrielle et Générale - Prévoyance, Organisation, Commandement, Co-ordination, Contrôle, Bulletin de la Societe de L'Industrie Minérale. 1916.

Fleishman, E.A. The description of supervisory behavior. Journal of Applied Psychology. $1953,37,1-6$.

Fleishman, E.A. Leadership Opinion Questionnaire. Chicago, Illinois: Science Research Associates, 1960.

Fleishman, E.A. Twenty years of consideration and structure. In Fleishman, E.A. \& Hunt, J.G. (Reds.) Current Developments in the study of Leadership. Carbondale: Southern Illinois University Press, 1973.

French, J. R. P. Role-playing as a method of training foremen. Sociometry, 1945, 8, 410-422.

French, J.R.P. (Jr.), Sherwood, J.J. \& Bradford, D.L. Change in self-identity in a management training conference. Journal of Applied Behavioral Science, 1966, 2, 210-218.

Goldstein, A.P. \& Sorcher, M. Changing Supervisory Behavior. New York: Pegamon, 1974.

Guest, R.H. Of time and the foremen. Personnel, 1956, 32, 478-486.

Gulick, L. \& Urwick, L. (Reds.) Papers on the Science of Administration. New York: Institute of Public Administration, 1937.

Haimann, T. \& Scott, W.G. Management in the Modern Organization. Boston: Houghton Mifflin, 1974.

Hall, D.T. \& Nougaim, K.E. An examination of Maslow's need hierarchy in an organizational setting. Organizational Behavior and Human Performance, 1968, 3, 12-35.

Hampden-Turner, C. An existential "learning theory" and the integration of T-group research. Journal of Applied Behavioral Science, 1966; 2, 367-386.

Harrison, R. Defenses and the need to know. Human Relations Training News, 1962, 6,(4), 14.

Harvey, O.J. \& Beverly, G.D. Some personality correlates of concept change through roleplaying. Journal of Abnormal and Social Psychology, 1961, 63, 125-130.

Hemphill, J.K. \& Coons, A.E. Development of the leader behavior description questionnaire. In Stogdill, R.M. \& Coons, A.E. (Reds.) Leader Behavior: Its description and Measurement. Columbus: Ohio State University Bureau of Business Research, Research Monograph No. 88, 1957, 6-38.

Hinrichs, J.R. Personnel training. In Dunnette, M.D. (Red.) Handbook of Industrial and Organisational Psychology. Chicago: Rand McNally, 1976.

Herzberg, F., Mausner, B. \& Snyderman, B. The Motivation to Work. New York: Wiley, 1959.

Home, J.H. \& Lupton, T. The work activities of "middle" managers. The Journal of Management Studies, 1965, 1, 14-33.

Huizinga, G. Maslow's Need Hierarchy in the Work Situation. Groningen: WoltersNoordhof Publishing Co., 1970.

Ingersoll, V.H. Role playing attitude change and behavior. Organizational Behaviour and Human Performance, 1973, 10, 157-174. 
Janis, I.L. \& King, B.T. The influences of role-playing on opinion change. Journal of Abnormal and Social Psychology, 1954, 49, 211-218.

Johnson, P.D. \& Sorcher, M. Behavior modelling training: Why, how, and what results. Journal of European Training, 1976, 5, 62-70.

Kahn, R.L. Organizational development: Some problems and proposals. Journal of Behavioral Science, 1974, 10, 485-502.

King, B.T. \& Janis, I.L. Comparison of the effectiveness of improvised versus nonimprovised role-playing in producing opinion changes. Human Relations, 1956, 9, 177 186.

Kirkpatrick, D.L. Techniques for evaluating training programmes. Training and Development Journal, 1979, 33, 78-92.

Koontz, H. \& O'Donnell, C. Principles of Management: An Analysis of Managerial Functions. New York: McGraw-Hill, 1955.

Korman, A.K. "Consideration", "Initiating Structure" and organizational criteria - A review. Personnel Psychology, 1966, 19, 349-361.

Kraut, A.I. Behavior Modeling Symposium: Developing managerial skills via modeling techniques: Some positive research findings. Personnel Psychology, 1976, 29, 325-328.

Latham, G.P. \& Saari, L.M. Application of social-learning theory to training supervisors through behavioral modeling. Journal of Applied Psychology, 1979, 64, 239-246.

Lawler, E.E. Motivation in Work Organizations. Belmont, California: Brooks/Cole, 1973.

Lichtenstein, E., Keutzer, C.S. \& Himes, K.H. Emotional role-playing and changes in smoking attitudes and behavior. Psychological Reports, 1969, 25, 379-387.

Locke, E.A. The myths of behavior modeling in organizations. Academy of Management Review, 1977, 2, 543-553.

Mann, J.H. Experimental evaluations of role-playing. Psychological Bulletin, 1956, 53, 227234.

Maslow, A.H. Motivation and Personality. New York: Harper, 1954.

McFall, R.M. \& Marston, A.R. An experimental investigation of behavior rehearsal in assertive training. Journal of Abnormal Psychology, 1970, 76, 195-303.

McGhee, W. \& Tullar, W.L. A note on evaluating behavior modification and behavior modeling as industrial training techniques. Personnel Psychology, 1978, 31, 477-483.

Minitzberg, H. The Nature of Managerial Work. New York: Harper and Row, 1973.

Moses, J.L. \& Ritchie, R.J. Supervisory relationships training: A behavioral evaluation of a behavior modeling program. Personnel Psychology, 1976, 29, 337-343.

Newman, W. III, Summer, C.E. \& Warren, E.K. The Process of Management. Englewood Cliffs, New Jersey: Prentice-Hall, Inc., 1967.

Petasis, A.P. \& Hancock, P.M.J. Effective black supervisory behavior and training in handling black poor performers and late comers. Psychologia Africana, 1979, 18, 1-21.

Peters, D.R. Self-ideal congruence as a function of human relations training. Journal of Psychology, 1970, 64, 199-207.

Rackham, N. \& Morgan, T. Behavior Analysis in Training. London: McGraw-Hill, 1977.

Robinson, J.C. Will behavior modeling survive the 80's? Training and Development Journal, 1980, 34, 22-28.

Saha, S.K. Contingency theories of leadership: A study. Human Relations, 1979, 32, $313-$ 322.

Scott, W.A. Attitude change through reward of verbal behavior. Journal of Abnormal and Social Psychology, 1957, 55, 72-75.

Scott, W.A. Attitude change by response reinforcement: Replication and extension. Sociometry, 1959, 22, 328-335. 
Shaw, M.E. Organizational considerations in role-playing application. Group Psychotheraphy, 1959, 12, 156-160.

Smith, P.E. Management modeling training to improve morale and customer satisfaction. Personnel Psychology, 1976, 29, 351-359.

Sorcher, M.A. A behavior modification approach to supervisor training. Professional Psychology, 1971, 2, 401-402

Sorcher, M.A. Behavior modeling: A new approach to supervisory training. People and Profits, 1975, 3, 26-29.

Stewart, R. The Reality of Management. London: William Heineman, 1963.

Taft, R. Multiple methods of personality assessment. Psychological Bulletin, 1959, 56, 333352.

Vroom, V.H. Work and Motivation. New York: Wiley, 1964.

Vroom, V.H. Leadership. In Dunnette, M.D. (Red.), Handbook of Industrial and Organizational Psychology. Chicago: Rand McNally College Publishing Co., 1976.

Whaba, M.A. \& Bridwell, L.G. Maslow reconsidered: A review of research on need hierarchy theory. Organizational Behavior and Human Performance, 1976, 15, 212-240.

Wehrenberg, S. \& Kuhnle, R. How training through behavior modeling works. Personnel Journal, 1980, 33, 576-581.

White, R.W. Motivation reconsidered: The concept of competence. Psychological Review, 1959, 66, 297-333.

Wofford, J.C. The motivational basis of job satisfaction and job performance. Personnel Psychology, 1971, 24, 501-508.

Ziggler, E. \& Child, I.L. Socialization. In Lindsey, G. en Aronson, E. (Reds.) Handbook of Social Psychology. Reading, Massashucetts: Addison-Wesley, 1969.

Zimbardo, P.G. The effect of effort and improvisation in self-persuation produced by roleplaying. Journal of Experimental Psychology, 1965, 1, 103-120.

\section{VERWYSINGSNOTA}

1. Onbekend - Stat Basic Program Reference Manual. New York: IBM Corporation Technical Publications, 1973. 